Older People: Their Support and Care 
By the same author

\section{Health Needs of the Elderly}


Older People: Their Support and Care

Gill Garrett

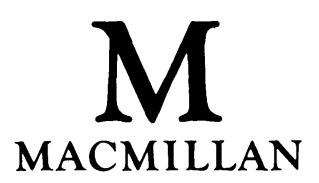


All rights reserved. No reproduction, copy or transmission of this publication may be made without written permission.

No paragraph of this publication may be reproduced, copied or transmitted save with written permission or in accordance with the provisions of the Copyright, Designs and Patents Act 1988, or under the terms of any licence permitting limited copying issued by the Copyright Licensing Agency, 90 Tottenham Court Road, London W1P 9HE.

Any person who does any unauthorised act in relation to this publication may be liable to criminal prosecution and civil claims for damages.

First published 1990 by

MACMILLAN EDUCATION LTD

Houndmills, Basingstoke, Hampshire RG21 2XS

and London

Companies and representatives

throughout the world

ISBN 978-0-333-51481-8

DOI 10.1007/978-1-349-11253-1

ISBN 978-1-349-11253-1 (eBook)

A catalogue record for this book is available from the British Library

Reprinted 1992 
For David 



\section{Contents}

Acknowledgements viii

Preface $\quad$ ix

1 . 'In the eye of the beholder' 1

2 - Health and happiness 11

$3 \cdot$ Growing older 19

4 - Staying put 27

$5 \cdot$ Support networks 43

6 - Being cared for 56

7 - Illness in the older person 68

8 - Major health problems $\quad 80$

9 . 'To live until you die' 101

Conclusion: Learning to care 116

Appendix 1: Useful addresses 118

Appendix 2: Further reading 120

$\begin{array}{ll}\text { Index } & 123\end{array}$ 


\section{Acknowledgements}

The author and publishers wish to thank the following photographic sources: Age Concern England pages 13, 39, 47, 73 bottom, 98; Barnaby's Picture Library pages 36, 72; Camera Press Ltd page 4, 61; J Allan Cash pages x, 3, 19, 40, 44, 112; Colorplast Ltd page 85; Sally \& Richard Greenhill page 70; Chris Kelly page 73 top; Topham Picture Library page 41.

The publishers have made every effort to trace the copyright holders, but if they have inadvertently overlooked any, they will be pleased to make the necessary arrangements at the first opportunity. 


\section{Preface}

As the demographic tide continues to change our population profile towards an older and still ageing society, it becomes increasingly important for all groups with a 'caring' commitment to understand older people. The lives they lead, their contributions and their needs are vital considerations for students preparing to work with them, whether in a professional or a voluntary capacity, in community or institutional settings.

This book is intended as a broad backcloth against which age and ageing can be studied. It is written from a practical perspective, with numerous case studies and exercises for completion. The situations depicted within it seek to familiarise those new to the support and care of older people with the experiences they are likely to meet - as care assistants in residential homes, as nursing auxiliaries or support workers with health authorities, or as students on a variety of caring programmes.

My thanks are due to my husband, David Norfolk, for all the practical help and advice he has given me, and for his unfailing support whilst the book was being written. It could not have been done without him.

Gill Garrett

Bristol, March 1989 


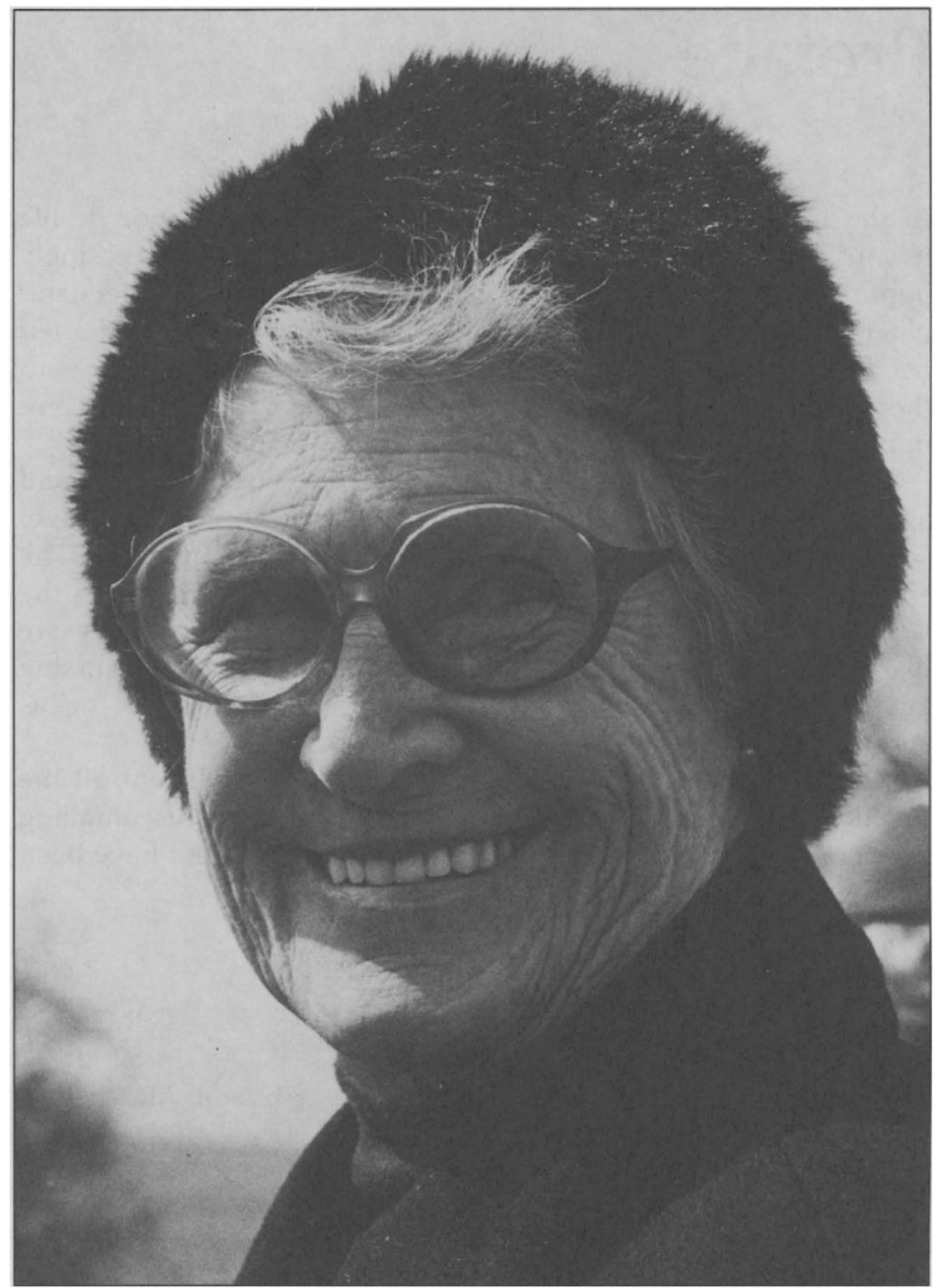

'Grow old along with me! The best is yet to be.' (Robert Browning) 